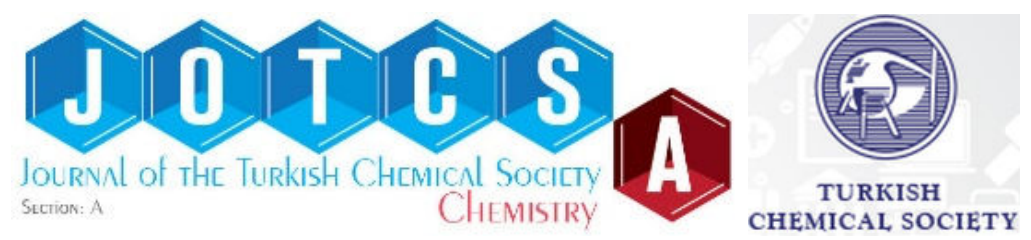

(This article was presented to the 28th National Chemistry Congress and submitted to JOTCSA as a full manuscript)

\title{
Effect of the Sizing Compound on the Electropolymerization of Pyrrole and the Impedance of Carbon Fiber Coated with Polypyrrole
}

\author{
Hacer DOLAS ${ }^{1}$, Digdem GIRAY ${ }^{1}$ and A.Sezai SARAC ${ }^{2 *}$ \\ ${ }^{1}$ Harran University, Chemistry Department and Vocational School of Hilvan, Sanliurfa, \\ TURKEY. \\ 2 İstanbul Technical University, Chemistry Department and Polymer \& Science \\ Technology, Maslak- İstanbul, TURKEY.
}

\begin{abstract}
Carbon Fiber (CF) is used as a strengthening material in resin composites having high performance in most industrial areas due to the fact that it has mechanical properties such as low weight, high durability, and toughness. The mechanical performances of composite materials depend on the features of fiber and matrix which composed them. The one of methods which improves the features of fiber surface is the coating on fiber surface with thin film. When the fiber was coated with electropolymer, the mechanical durability of the composite was increased. In this study, carbon fibers were electrochemically coated with polypyrrole (PPy) in the presence of sizing compound (SC) based on epoxy. During the process, it was investigated that how current, obtained coating weights and impedance data, especially capacitance, changed by the amount of $\mathrm{SC}$. For this reason, different amounts of SC (\%0; \% $0.18 ; \% 1.8 \mathrm{v} / \mathrm{v})$ was added into the electrolyte solution ( $0.1 \mathrm{M} \mathrm{NaClO}_{4}-\mathrm{ACN}$ ) including $0.1 \mathrm{M}$ Pyrrole (Py). Coating process was carried out by using Constant Potential or Cyclic Voltammetry Techniques. Other techniques for investigations were gravimetrical analysis, electrochemical impedance spectroscopy, Fourier Transform Infrared Spectroscopy (FT-IR) and Light Microscopy. At the end of the coating, the weight of coating and specific capacitance (Csp) values were $0.8 \mathrm{mg} / \mathrm{g}$ and $114 \mu \mathrm{F}$ for $\% 0$ of SC $10 \mathrm{mg} / \mathrm{g}$ and $57 \mu \mathrm{F}$ for $\% 0.18$ of SC and $1.73 \mathrm{mg} / \mathrm{g}$ and $166 \mu \mathrm{F}$ for \%1.8 of SC, respectively. As a result, the coating weight and capacitance data (especially, Csp, ) of carbon fiber coated with PPy were inversely changed with the amount of SC added into electrolyte.
\end{abstract}

Keywords: Electropolymerization, Sizing, Impedance and Capacitance.

Submitted: June 9, 2016. Revised: August 16, 2016. Accepted: August 17, 2016.

Cite this: Dolaş H, Giray D, Saraç A. Effect Of The Sizing Compound On The

Electropolymerization Of Pyrrole And The Impedance Of Carbon Fiber Coated With

Polypyrrole. JOTCSA. 2016;3(3):281-298.

DOI: $10.18596 /$ jotcsa.20551.

*Corresponding authors. E-mail: hacerdolas@hotmail.com and sarac@itu.edu.tr. 


\section{INTRODUCTION}

Carbon Fiber (CF) is used as a strengthening material in resin composites having high performance which is mostly used in the fields of industry, space, and textile due to having mechanical properties such as low weight, high durability, and strength [1-4]. The mechanical properties of composite materials are based on the properties of fiber and matrix which constitute it. Developing these properties is possible the control of intermediate surface formed between fiber and matrix. Intermediate surface plays an important role for controlling the mechanical properties such as the shearing inter layers and impact resistance of composite. A strong and durable intermediate surface can effectively transfer the load from matrix to fiber. Fiber/matrix interaction depends on chemical bonds formed from interaction between active groups existing in matrix resin and polar group such as hydroxyl and carboxyl on the surface of fiber [5-7]. Various methods were developed for raising the wettability of and functional group number on fiber surface [8-11]. Methods such as the electrochemical oxidizing [12-14], the oxidizing in acidic medium using nitric or phosphoric acid [15-19], plasma [20-22], and radiation $[23,24]$ were used for developing the performance of intermediate surface between fiber and matrix. Another method is coating with thin polymer film [25-27]. The film thickness and functionality of the formed coating can control with electrochemical coating method using method parameters (current density, potential, monomer concentration, and temperature, etc. ) [28-33]. It is well known that while CF is obtained, it is sized with various adding (sizing) compounds. Also, the effect of sizing compound (SC) on the surface roughness, surface reactive group number, and wettability of the fiber were investigated [34]. When CFs based on polyacrylonitrile (Poly(AN), PAN) was treated with $\mathrm{J} 4$ and A436 emulsion type sizing compound, it was observed the decreasing on the average surface roughness (Ra) [35]. Acidic filling materials demonstrate more interaction durability with epoxy matrix [36]. It is considered that Ra decreased because of the filling of hollow between strains on surface of the fiber [37]. As CF was sized by electropolymerization, the mechanical strength of composite was increased. The impact, bend and shear strength of phenolic resin-based composite respectively were $44 \%, 68 \%$ and $87 \%$ when $\mathrm{CF}$ was reinforced with $\mathrm{m}$-phenylenediamine. During mechanical test, composite including unsized CF possessed holes due to getting out the CF [38]. This behavior is caused that unsized CF surface does not carry convenient groups to hold on to matrix. This problem could be decreased when CFs are sized by electropolymerization. As a result, electropolymerization is a convenient method for CF sizing process [38].CF were electropolymerized with monomers including groups such as $-\mathrm{OH},-\mathrm{NH}_{2}$ or $-\mathrm{COOH}$ by using Cyclic Voltammetry (CV) or Chronoamperometry to develop surface features. At the end of this process, CFs were sized [38].CF was electrochemically coated with polyethylendioxythiophene (PolyEDOT) [39], PolyAN [40, 41], Polypyrrole (PolyPy) [42], 
and their derivatives $(43,44)$. The capacitivity and roughness of CF were increased by using this method [45]. Also it was reported that Poly(Py) contribute to the strength of composite [42]. Electrochemical Impedance Spectroscopy (EIS) was used as a spectroscopic technique to analyze electrochemical process occurring at the electrolyte/electrode interface and to investigate the charge transfer, ion diffusion and capacitor behavior of conducting polymer modified electrodes [46-48]. In the literature, the capacitive features of carbon fiber (CF) electrodes modified by conducting polymer such as poly( $\mathrm{N}$-methyl pyrrole) [45], polythiophene and poly(N-methylpyrrole) [49], Npyrrole, N-phenylpyrrole, and 1[4-methoxyphenyl]-1H-pyrrole homopolymers [50], poly(3-dodecylthiophene) [48], poly(3-methylthiophene) [51], poly(thiophene-imidazole) [52], were characterized by EIS. It was signed that the value of impedance for the electrode coated poly(3-methylthiophene) was affected with the morphology of coating and also the morphology was affected with the present electrolyte [51]. In this study, we aimed to investigate how SC affects on and the electropolymerization of Py and the impedance data of PolyPy coated CF. For this reason, CFs was electrocoated with polypyrrole (PolyPy) conducting polymer by using constant or cyclic potential in the presence of epoxy based sizing compound (SC) in electrolyte solution. The coating thickness (as weight) and capacitive features of obtained coated CF and the current flown through system were investigated.

\section{EXPERIMENTAL}

In this study, we used CFs that were coated electrochemically with Py monomer (0.1 M) by using Constant Potential $(1.5 \mathrm{~V})$ in three electrode system, Ag wire (calibrated with $0.1 \mathrm{M}$ ferrocene) as reference electrode, Pt wire as counter electrode and CF (0.003 \pm $0.0005 \mathrm{~g}$ and $6 \mathrm{~cm}$ ) as the working electrode. Electrolyte solution contained different amounts $(0 \% ; 0.18 \%$ and $1.8 \%$ ) of epoxy based SC (Chemetylen AK-2 (SANYO Chemical Industries, Ltd.) in $0.1 \mathrm{M}$ sodium perchlorate (0.1 $\left.\mathrm{M} \mathrm{NaClO}_{4}\right)$-acetonitrile (ACN) [48-50].

\section{The Constant Potential Electropolymerization (CPE) of Fibers}

The aim of this part was to investigate the effect of SC on current which is flown in the circuit, so to follow the change of weight of coating with amount of SC in the electrolyte solution. During $60 \mathrm{~min}$, the current flown through the system was recorded in CPE. Obtained data vs. time were given in Table 1.

Table 1: Obtained from CPE the current-time data. ( $\mathrm{NaClO}_{4} / \mathrm{ACN} ; 0.003 \mathrm{~g} \mathrm{CF} ; 1.5 \mathrm{~V}$ )

\begin{tabular}{|c|c|c|c|c|c|c|c|c|c|c|}
\hline Current/ $\mu \mathrm{A}$ & 18 & 17.94 & 17.65 & 17.65 & 17.21 & 17.14 & 17.21 & 17 & 17 & 16.6 \\
\hline Time/min. & 0.1 & 3.52 & 9.86 & 16.1 & 28 & 33 & 41 & 47 & 58 & 60 \\
\hline
\end{tabular}


In the first experiment, SC was not added into the electrolyte to see the difference of SC. Other experiments were carried out by adding $0.18 \%(\mathrm{w} / \mathrm{v})$ and $1.8 \%(\mathrm{w} / \mathrm{v})$ of SC to compare and find the convenient amount of SC. Obtained data were given Table 2 and Table 3.

Table 2: Obtained from CPE the current-time data. (SC: $0.18 \% ; \mathrm{NaClO}_{4} / \mathrm{ACN} ; 0.003 \mathrm{~g}$

$$
\text { CF; } 1.5 \mathrm{~V} \text { ) }
$$

\begin{tabular}{|c|c|c|c|c|c|c|c|c|c|c|c|}
\hline Current/ $\mu \mathrm{A}$ & 10.9 & 11.28 & 12 & 13.09 & 13.59 & 13.52 & 13.45 & 13.67 & 13.74 & 13.59 & 13.59 \\
\hline Time/min. & 1.71 & 5.88 & 9.86 & 17 & 27 & 32 & 40 & 46 & 50 & 54 & 60 \\
\hline
\end{tabular}

When the amount of SC was $0 \%$, current changing was not observed during process, at $60 \mathrm{~min}$ and its value was about $17 \mu \mathrm{A}$. This current value was recorded as $13 \mu \mathrm{A}$ for $0.18 \%$ of SC. This result pointed to the finding that the SC decreased current value. However, the current increased during the process and the weight of coating reached 10 $\mathrm{mg} / \mathrm{g}$ for $0.18 \% \mathrm{SC}$. It was, however, $0.8 \mathrm{mg} / \mathrm{g}$ for $0 \% \mathrm{SC}$.

Table 3: Obtained from CPE the current-time data. (SC: $1.8 \% ; \mathrm{NaClO}_{4} / \mathrm{ACN} ; 0.003 \mathrm{~g} \mathrm{CF}$;

\begin{tabular}{|c|c|c|c|c|c|c|c|c|c|c|c|}
\hline \multicolumn{12}{|c|}{$1.5 \mathrm{~V})$} \\
\hline Current/ $\mu \mathrm{A}$ & 10.7 & 0.6 & 0.4 & 0.42 & 0.49 & 0.49 & 0.42 & 0.63 & 0.7 & 0.63 & 0.63 \\
\hline Time/min. & 0.1 & 4.07 & 9.6 & 14 & 19 & 28 & 36 & 45 & 53 & 57 & 60 \\
\hline
\end{tabular}

According to Table 3, in these conditions the current passed from circuit was $10.7 \mu \mathrm{A}$ within the first minute. Then the value decreased to $0.4 \mu \mathrm{A}$. The weighed amount of coating was $1.73 \mathrm{mg} / \mathrm{g}$. As a result, the coating came true in the first minute. The amount of SC promoted the coating. It was however seen that the excess amount of SC was inhibited the current passing. When coating weight was $0.8 \mathrm{mg} / \mathrm{g}$ for $0 \% \mathrm{SC}$, it was $10 \mathrm{mg} / \mathrm{g}$ for $0.18 \% \mathrm{SC}$. Surprisingly, while the weight was decreased to $1.73 \mathrm{mg} / \mathrm{g}$, the current was decreased $0.63 \mu \mathrm{A}$ for $1.8 \% \mathrm{SC}$. When compared with $0.18 \% \mathrm{SC}$, the reason of this decrease was thought that the current passing and coating were blocked by the excessive amount of SC.

\section{Gravimetric Analysis}

To see how the adding of various amount of SC in electrolyte solution affected on the amount of coating, after CPE, CFs coated with PolyPy were weighted by using a five-digit analytical balance. The obtained data were given in Table 4. 
Table 4: The amount of coating as compared the different amount of SC. (0.003 gr CF;

\begin{tabular}{|l|l|l|l|}
\hline SC $(\%)$ & 0 & 0.18 & 1.8 \\
\hline Weight $(\mathrm{mg} / \mathrm{g})$ & 0.8 & 10 & 1.73 \\
\hline
\end{tabular}

According to obtained data, as SC was added in electrolyte solution during electrocoating, a decrease in the coating amount was observed. When SC amount was $0.18 \%$, coating amount was $10 \mathrm{mg} / \mathrm{g}$. This increasing was attributed to including into the structure of coating. But it was determined that the increasing in the amount was inhibited, while the amount of SC added in electrolyte solution was more than $0.18 \%$, the increasing of coating amount was inhibited. Also, this increase was supported with the current rise (Table 2 and 3). Depended on these results, it is concluded that the current and SC amount were important parameters on the controlling of the thickness or amount of coating.

\section{Structural Analysis (FTIR-ATR)}

In the data, FT-IR peaks were investigated to understand whether if SC was included into the structure of the coating. The FT-IR spectra of CF coated with PPy in the presence of the various ratios of SC were compared in Figure 1. When we look at the figure, it was considered that the characteristic peaks of CF were covered with coating (PolyPy) and the characteristic peaks of coating were seen in the spectrum. The peak of PPy was seen in $3800-3600 \mathrm{~cm}^{-1}$, and the ones of SC in $2900-2800 \mathrm{~cm}^{-1}$. The related peak assignments were given in Table 5 .

Table 5. The FTIR-ATR peak assignments.

\begin{tabular}{|l|l|}
\hline Peak $\left(\mathbf{c m}^{-\mathbf{1}}\right)$ & Peak Type \\
\hline 3748 & N-H stretching[53] \\
\hline $2872,1682,1711$ & SC \\
\hline 1537,1452, & PolyPy ring vib.[53] \\
\hline $1312,1089,1072,1040$ and 889 & $=$ CH band vib. of PPy[53] \\
\hline
\end{tabular}




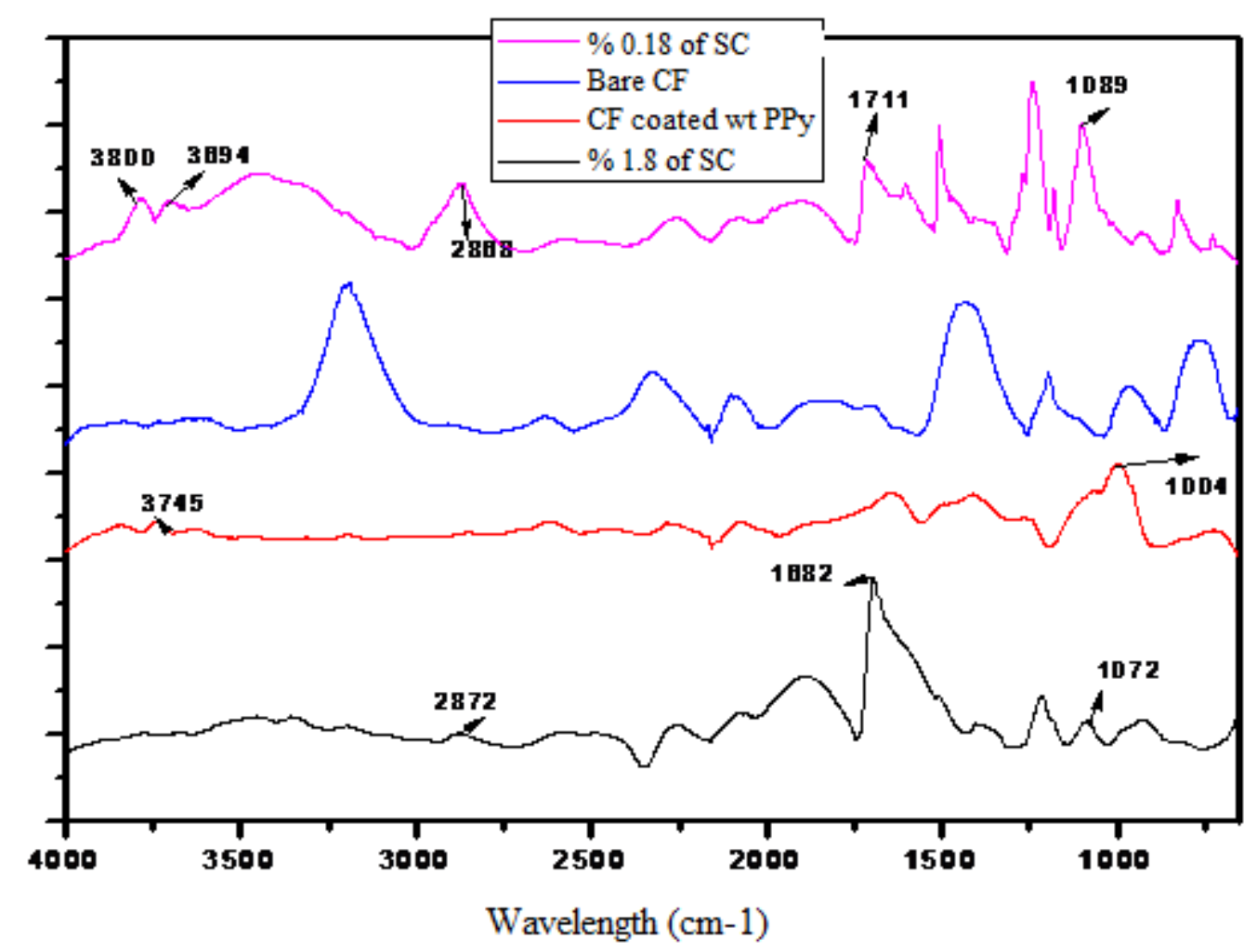

Figure 1. The FTIR-ATR spectra of CF coated with PolyPy in presence of SC $(0.18 \%$; $1.8 \%)$.

Peaks at 1452 and $1537 \mathrm{~cm}^{-1}$ were assigned to Py ring vibration. The ones at 1312 and $1040 \mathrm{~cm}^{-1}$ were presented as the $=\mathrm{C}-\mathrm{H}$ band vibrations. The $\mathrm{N}-\mathrm{H}$ stretching vibration was observed at $3745 \mathrm{~cm}^{-1}$. The peaks at 1178, 1089, 1072 and $889 \mathrm{~cm}^{-1}$ were characteristic peaks of $=\mathrm{C}-\mathrm{H}$ out of plane vibration, demonstrating the polymerization of Py [53]. It was considered that the peaks at 2872,1682 and $1711 \mathrm{~cm}^{-1}$ belonged to SC.

\section{The Cyclic Voltammetry-Induced Electropolymerization of Fibers:}

To investigate the effect of SC on the impedance values (or capacitance values), it was required to prepare CFs thin layer coated with PolyPy. For this reason, cyclic voltammetry technique was used. A three-electrode system consisted of $\mathrm{Ag}$ wire as a reference electrode, Pt wire as a counter electrode, and single CF as a working electrode like CPE. $\mathrm{SC}$ was added in $0.1 \mathrm{M}$ Py including electrolyte solution $\left(\mathrm{NaClO}_{4}-\mathrm{ACN}\right)$ in various ratios, which were $0 \% ; 0.18 \%$ and $1.8 \%$. So, obtained CV graphs were given in Figure 2 . 


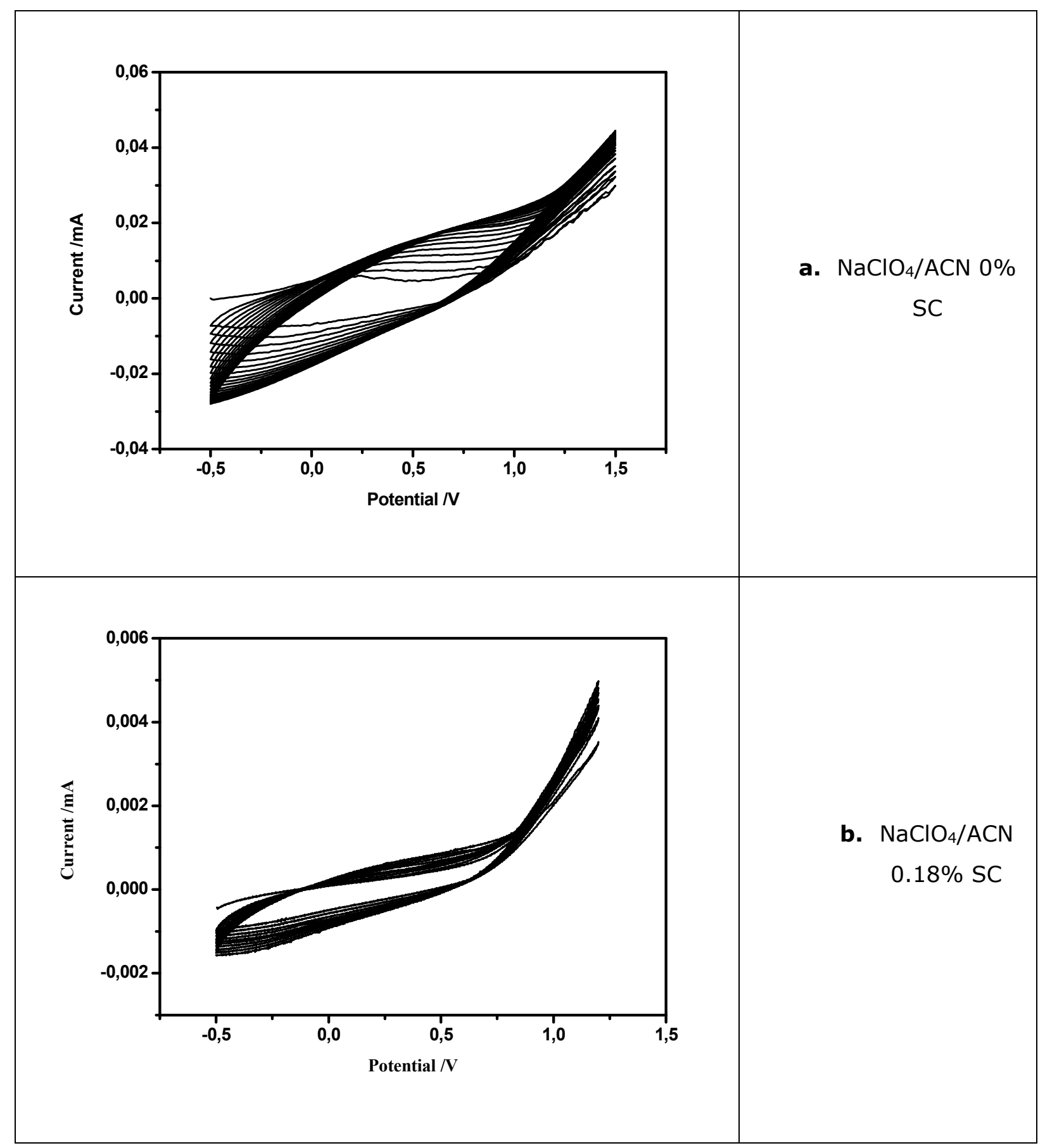




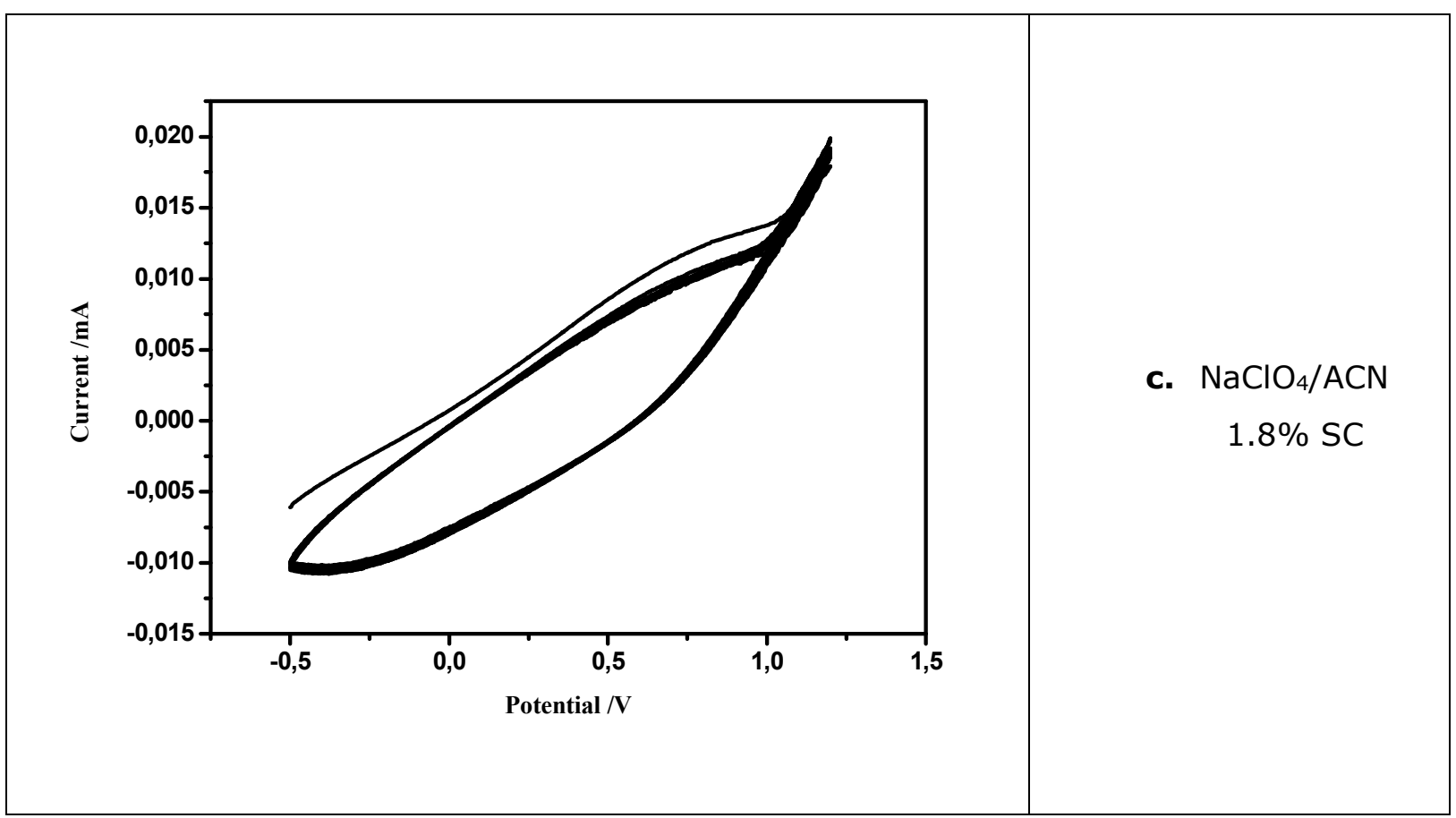

Figure 2. The CVs showing the effect of $\mathrm{SC}$ on polymerization of $\mathrm{Py}$ in $\mathrm{NaClO}_{4}-\mathrm{ACN}$ including various ratios of SC.

It was seen clearly that adding SC affected the shape of CV. Py was oxidized at $0.9 \mathrm{~V}$ and current value was $0.04 \mathrm{~mA}$ (Figure 2a). As SC was added in electropolymerization medium, the value was decreased at $0.005 \mathrm{~mA}$ for $\% 0.18 \mathrm{SC}$ and $0.02 \mathrm{~mA}$ for $1.8 \% \mathrm{SC}$. It was thought that the cause of raising value at $1.8 \% \mathrm{SC}$ might be due to the increasing amount of SC. To determine the electrical properties and if the mechanism of polymerization reaction is controlled by diffusion or not, it is required that CFs coated with PolyPy are investigated under CV conditions. Used electrolyte solution cannot include the monomer (here Py). For this reason, various scan rates were applied to CF coated with PPy and obtained CV graph, which were monomer-free graphs. The current responses to the scan rate from the polymer, oxidation (ox.) and reduction (red.) of the polymer peak current potentials and oxidation and reduction of the polymer peak current values were obtained from the graphs. Figure 3 illustrated scan rate vs. oxidationreduction peak current values. 


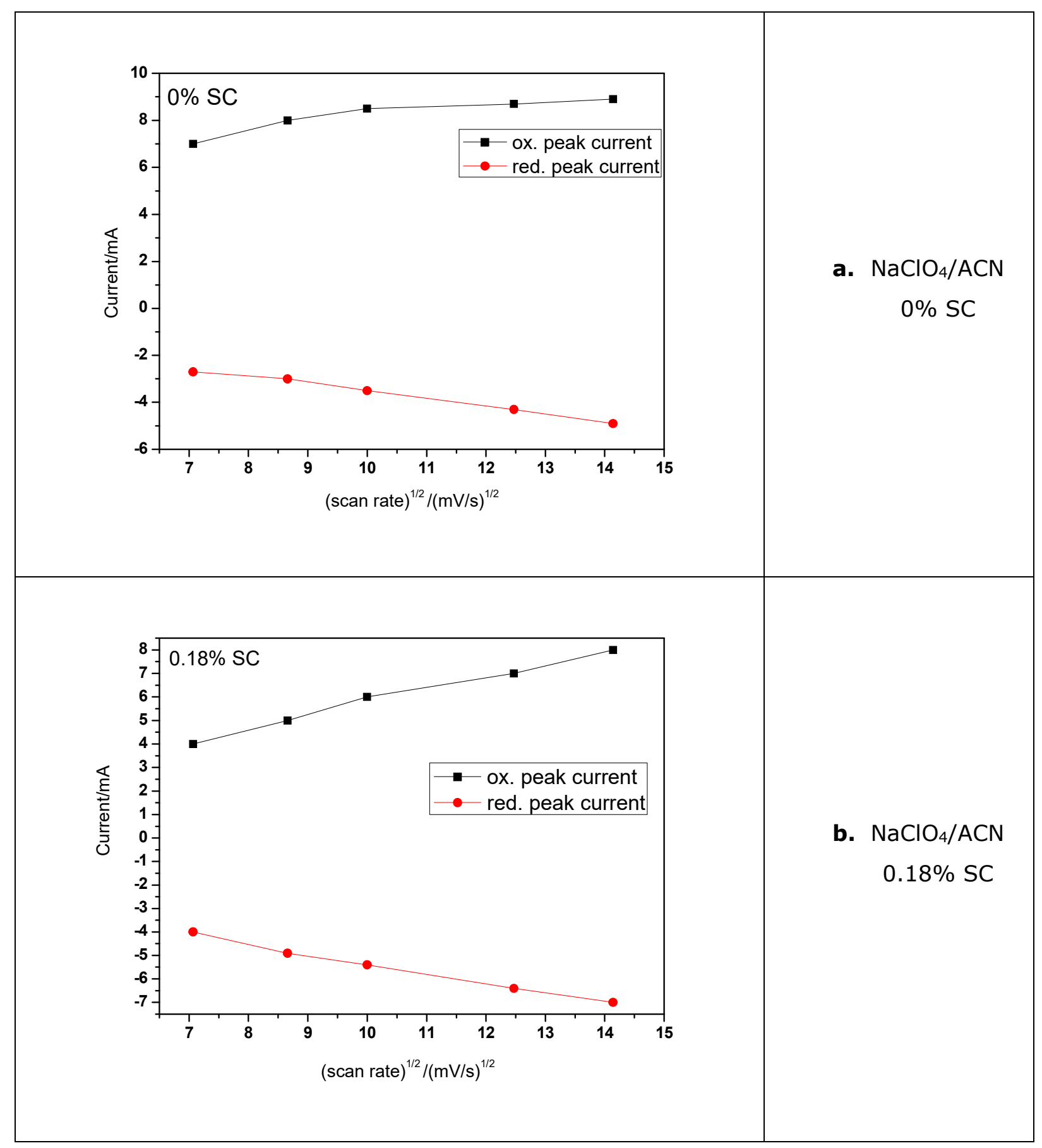




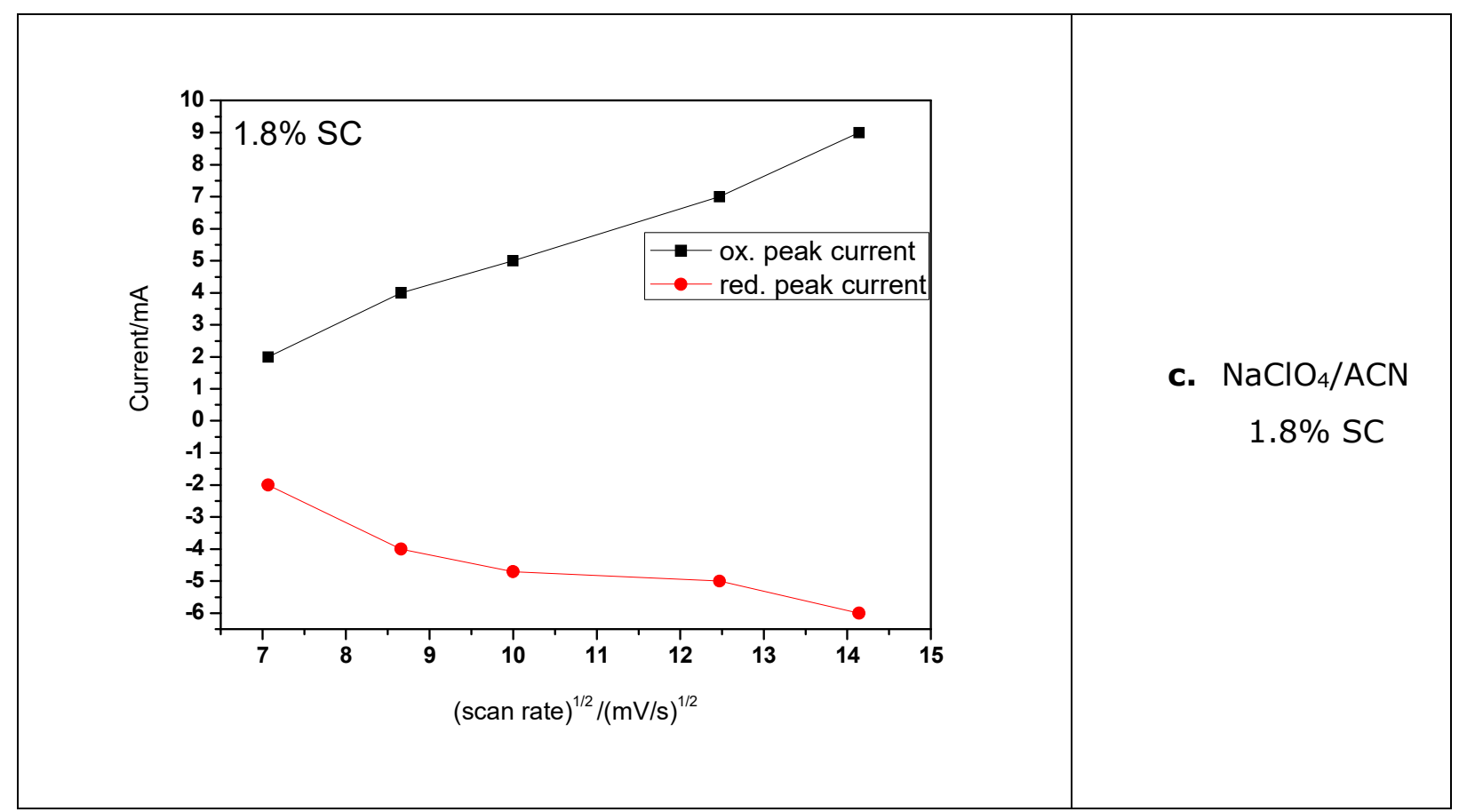

Figure 3. The monomer-free graphs of CFs coated with PPy in different conditions.

As the curve obtained from this data is approximated to a linear form, it could be concluded that the mechanism of polymerization reaction was controlled by diffusion. It can however be seen clearly that this control was destroyed by using of $1.8 \%$ SC in electrolyte medium.

\section{The Electrochemical Impedance Analysis of Coated Fibers}

To show and compare the effect of SC on electrochemical impedance, namely capacitance, the CFs obtained from related experiments were used. The measurements were taken in $\mathrm{NaClO}_{4}-\mathrm{ACN}$ solution by using Electrochemical Impedance Spectroscopy (EIS). Figure 4 illustrated EIS graphs (Nyquist, Bode-Phase, Bode-Magnitude, and admittance). 


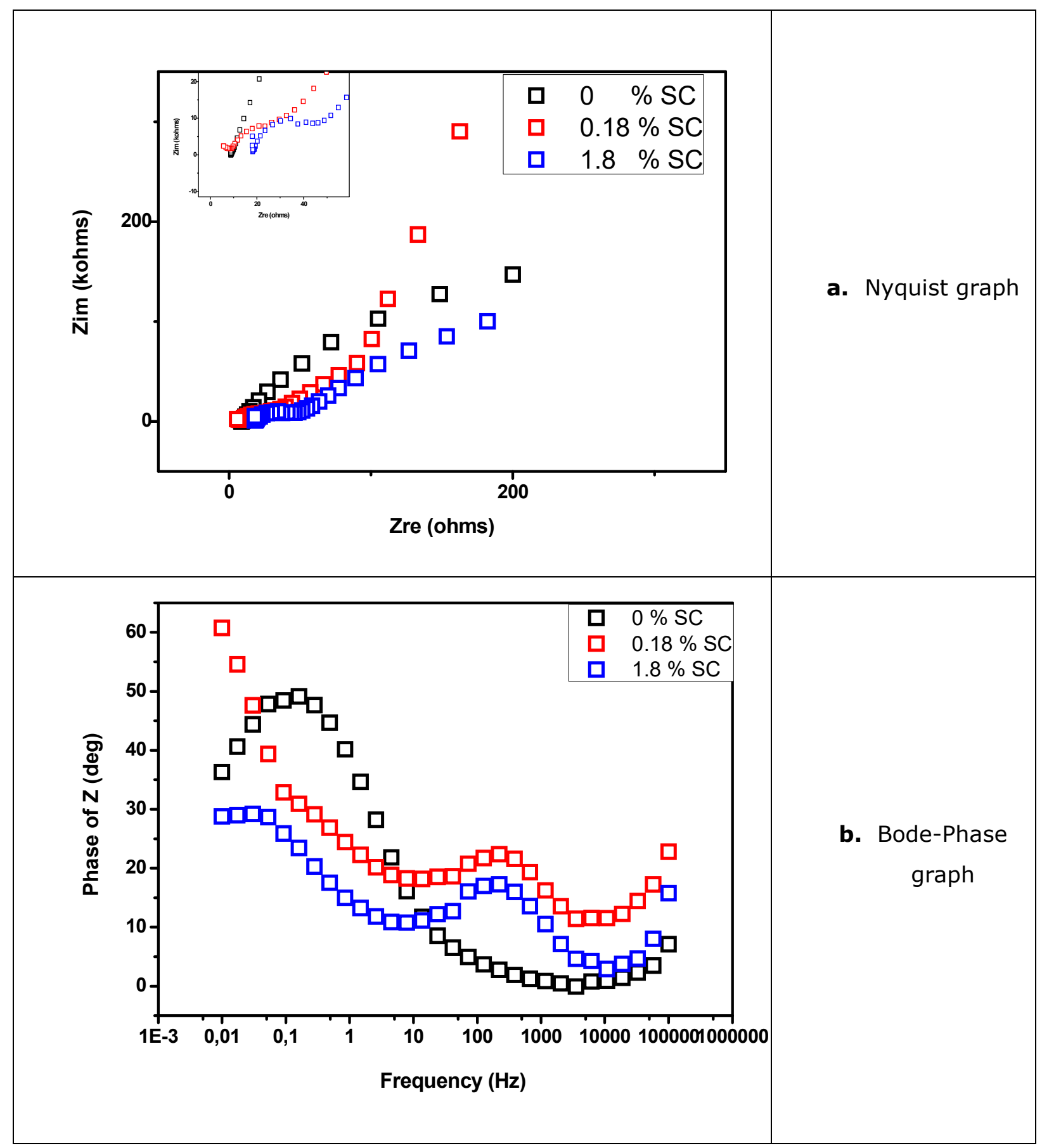




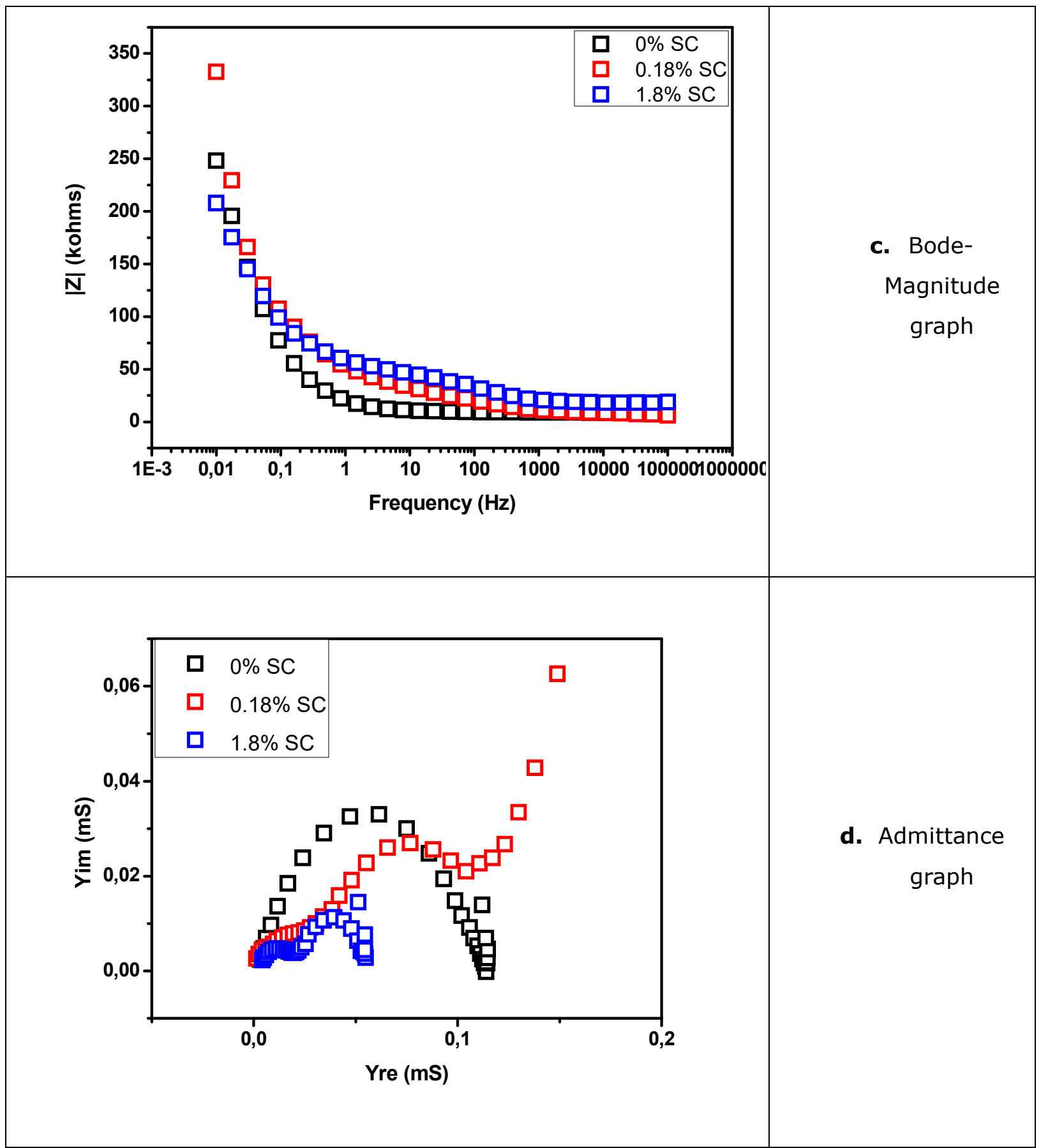

Figure 4. The EIS graphs of CFs coated with PPy in different conditions.

Different Capacitance values were obtained from these impedance graphs [54]. One of them was specific capacitance $\left(C_{s p}\right.$ ) calculated from Nyquist graph by using $Z_{i m}$ at lowest frequency. The other was Double Layer Capacitance $\left(C_{d l}\right)$ calculated from BodeMagnitude graph by using IZI at $1 \mathrm{~Hz}$. Calculated $C_{s p}$ and $C_{d l}$ values were $114 \mu \mathrm{F}$ and 45 $\mu \mathrm{F} ; 57 \mu \mathrm{F}$ and $19 \mu \mathrm{F} ; 166 \mu \mathrm{F}$ and $17 \mu \mathrm{F}$ for $0 \% ; 0.18 \% ; 1.8 \%$ of SC, respectively. Phase angle and admittance values were changed as $36^{\circ}$ and $32 \mu \mathrm{S} ; 61^{\circ}$ and $26 \mu \mathrm{S} ; 29^{\circ}$ and 11 uS for $0 \% ; 0.18 \% ; 1.8 \%$ of SC, respectively. 
In the light of this information, values obtained from these impedance graphs were given in Table 5. According to the values $C_{s p}$ value was changed by adding SC in electrolyte solution. This change was shaped bell curve reversely, but the changing of the coating weight was shaped bell curve.

Table 5. The changing of Csp and coating weight vs. the ratio of SC.

\begin{tabular}{|l|l|l|l|}
\hline SC $(\%)$ & 0 & 0.18 & 1.8 \\
\hline Csp $(\mu \mathrm{F})$ & 114 & 57 & 166 \\
\hline Weight $(\mathrm{mg} / \mathrm{g})$ & 0.8 & 10 & 1.73 \\
& & & \\
\hline
\end{tabular}

\section{Light Microscopic Images}

CF was coated with PolyPy in the presence of various ratios $(0 \%, 0.18 \%$, and $1.8 \%)$ of $\mathrm{SC}$ in the electrolyte. CF was used as brush (in CPE technique) or single (in CV technique) form. The images captured from light microscopy of CFs coated with PolyPy were shown in Figure 5. Single CF was illustrated in Fig.5a, brush CF in Fig.5b and the comparison of coated and uncoated of CFs in Fig5c. As seen in the figure, the coatings were homogenous.
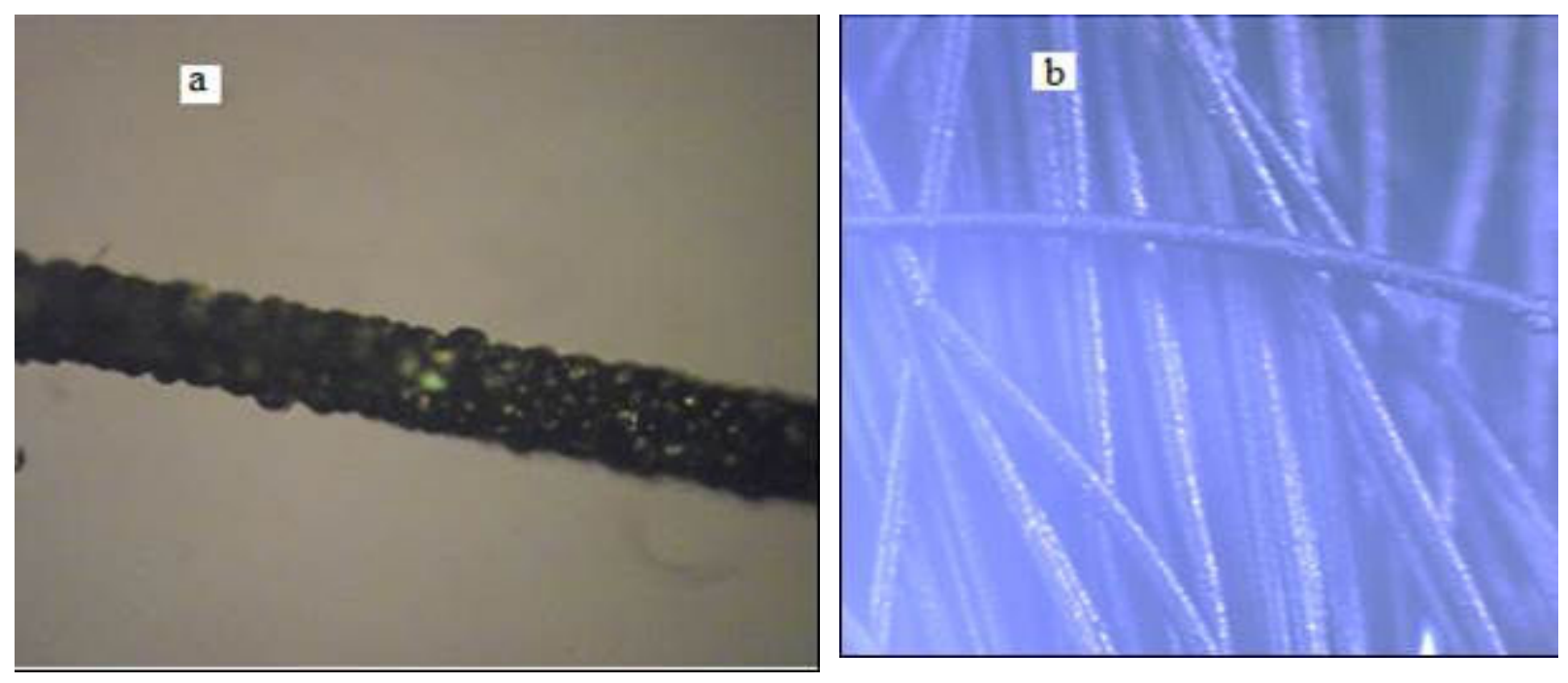


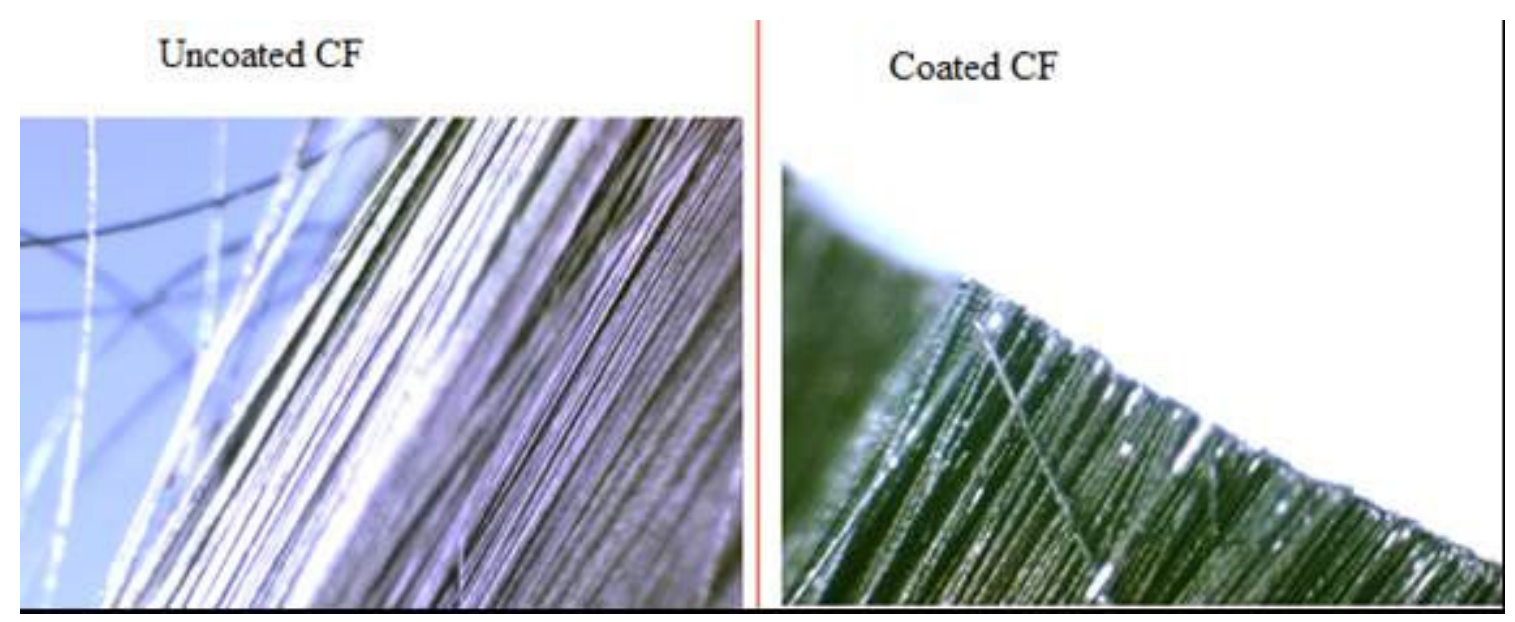

c)

Figure 5. The images of light microscopy of Single CF (a), brush CF (b) and the comparison of uncoated and coated CFs (c).

\section{DISCUSSIONS}

In this study, it was proved that SC presented in electrolyte affected to the electropolymerization of Py, the weight of coating, the electrical, impedance, and capacitance properties of CF coated with PPy by using convenient techniques (CPE, Analytical Balance, CV, EIS and Light Microscopy). As a result, the weights and the capacitance values of CFs coated with PolyPy in conditions such as $0.1 \mathrm{M} \mathrm{NaClO}{ }_{4}-\mathrm{ACN}$ electrolyte solution including $0.1 \mathrm{M}$ Py and various ratios of epoxy based SC $(0 \% ; 0.18 \%$ and $1.8 \%$ ) was changed with the SC ratios.

\section{REFERENCES}

1. Guo $H$, Huang $Y$, Liu L, Shi X. Effect of epoxy coatings on carbon fibers during manufacture of carbon fiber reinforced resin matrix composites. Materials \& Design. 2010;31(3):1186-90.

2. Rezaei F, Yunus R, Ibrahim NA. Effect of fiber length on thermomechanical properties of short carbon fiber reinforced polypropylene composites. Materials \& Design. 2009;30(2):260-3.

3. Bai $Y$, Wang $Z$, Feng L. Interface properties of carbon fiber/epoxy resin composite improved by supercritical water and oxygen in supercritical water. Materials \& Design. 2010;31(3):16136.

4. Montes-Morán MA, Gauthier W, Martínez-Alonso A, Tascón JMD. Mechanical properties of highstrength carbon fibres. Validation of an end-effect model for describing experimental data. Carbon. 2004;42(7):1275-8.

5. Park S-J, Jang Y-S. Interfacial Characteristics and Fracture Toughness of Electrolytically NiPlated Carbon Fiber-Reinforced Phenolic Resin Matrix Composites. Journal of Colloid and Interface Science. $2001 ; 237(1): 91-7$.

6. Choi $\mathrm{MH}$, Jeon $\mathrm{BH}$, Chung IJ. The effect of coupling agent on electrical and mechanical properties of carbon fiber/phenolic resin composites. Polymer. 2000;41(9):3243-52. 
7. Park S-J, Kim M-H, Lee J-R, Choi S. Effect of Fiber-Polymer Interactions on Fracture Toughness Behavior of Carbon Fiber-Reinforced Epoxy Matrix Composites. Journal of Colloid and Interface Science. $2000 ; 228(2): 287-91$.

8. Zielke U, Hüttinger KJ, Hoffman WP. Surface-oxidized carbon fibers: I. Surface structure and chemistry. Carbon. 1996;34(8):983-98.

9. Pittman Jr CU, He GR, Wu B, Gardner SD. Chemical modification of carbon fiber surfaces by nitric acid oxidation followed by reaction with tetraethylenepentamine. Carbon. $1997 ; 35(3): 317-31$.

10. Hughes JDH. The carbon fibre/epoxy interface-A review. Composites Science and Technology. $1991 ; 41(1): 13-45$

11. Yuan $\mathrm{H}$, Wang $\mathrm{C}$, Zhang S, Lin X. Effect of surface modification on carbon fiber and its reinforced phenolic matrix composite. Applied Surface Science. 2012;259:288-93.

12. Yue ZR, Jiang W, Wang L, Gardner SD, Pittman Jr CU. Surface characterization of electrochemically oxidized carbon fibers. Carbon. 1999;37(11):1785-96.

13. Gulyás J, Földes E, Lázár A, Pukánszky B. Electrochemical oxidation of carbon fibres: surface chemistry and adhesion. Composites Part A: Applied Science and Manufacturing. $2001 ; 32(3-4): 353-60$.

14. Severini F, Formaro L, Pegoraro M, Posca L. Chemical modification of carbon fiber surfaces. Carbon. 2002;40(5):735-41.

15. Seo M-K, Park S-J. Surface characteristics of carbon fibers modified by direct oxyfluorination. Journal of Colloid and Interface Science. 2009;330(1):237-42.

16. Li J. Interfacial studies on the $\mathrm{O} 3$ modified carbon fiber-reinforced polyamide 6 composites. Applied Surface Science. 2008;255(5, Part 2):2822-4.

17. Zhang X, Pei X, Zhang J, Wang Q. Effects of carbon fiber surface treatment on the friction and wear behavior of 2D woven carbon fabric/phenolic composites. Colloids and Surfaces A: Physicochemical and Engineering Aspects. 2009;339(1-3):7-12.

18. Fjeldly A, Olsen $T$, Rysjedal JH, Berg JE. Influence of the fiber surface treatment and hot-wet environment on the mechanical behavior of carbon/epoxy composites. Composites Part A: Applied Science and Manufacturing. 2001;32(3-4):373-8.

19. Ramanathan T, Bismarck A, Schulz E, Subramanian K. Investigation of the influence of acidic and basic surface groups on carbon fibres on the interfacial shear strength in an epoxy matrix by means of single-fibre pull-out test. Composites Science and Technology. 2001;61(4):599-605.

20. Montes-Morán MA, Martínez-Alonso A, Tascón JMD, Young RJ. Effects of plasma oxidation on the surface and interfacial properties of ultra-high modulus carbon fibres. Composites Part A: Applied Science and Manufacturing. 2001;32(3-4):361-71.

21. Dilsiz N, Erinç NK, Bayramli E, akovali G. Surface energy and mechanical properties of plasmamodified carbon fibers. Carbon. 1995;33(6):853-8.

22. Bubert H, Ai X, Haiber S, Heintze M, Brüser V, Pasch E, et al. Basic analytical investigation of plasma-chemically modified carbon fibers. Spectrochimica Acta Part B: Atomic Spectroscopy. 2002;57(10):1601-10.

23. Li J, Huang Y, Xu Z, Wang Z. High-energy radiation technique treat on the surface of carbon fiber. Materials Chemistry and Physics. 2005;94(2-3):315-21.

24. Xu Z, Huang Y, Zhang C, Liu L, Zhang Y, Wang L. Effect of Y-ray irradiation grafting on the carbon fibers and interfacial adhesion of epoxy composites. Composites Science and Technology. 2007;67(15-16):3261-70. 
25. Saraç AS, Bardavit Y. Electrografting of copolymer of poly[N-vinylcarbazole-co-styrene] and poly[N-vinylcarbazole-co-acrylonitrile] onto carbon fiber: cyclovoltammetric (CV), spectroscopic (UV-Vis, FT-IR-ATR), and morphological study (SEM). Progress in Organic Coatings. $2004 ; 49(2): 85-94$.

26. Blackketter DM, Upadhyaya D, King TR, King JA. Evaluation of fiber surfaces treatment and sizing on the shear and transverse tensile strengths of carbon fiber-reinforced thermoset and thermoplastic matrix composites. Polymer Composites. 1993;14(5):430-6.

27. Yumitori S, Wang D, Jones FR. Third International Conference on Interfacial Phenomena in Composite MaterialsThe role of sizing resins in carbon fibre-reinforced polyethersulfone (PES). Composites. 1994;25(7):698-705.

28. Lu W, Smela E, Adams P, Zuccarello G, Mattes BR. Development of Solid-in-Hollow Electrochemical Linear Actuators Using Highly Conductive Polyaniline. Chemistry of Materials. $2004 ; 16(9): 1615-21$.

29. Fukuhara T, Akiyama Y, Yoneda N, Tada T, Hara S. Effective synthesis of difluorocyclohexadienones by electrochemical oxidation of phenols. Tetrahedron Letters. 2002;43(37):6583-5.

30. Matsushita M, Kuramitz H, Tanaka S. Electrochemical Oxidation for Low Concentration of Aniline in Neutral pH Medium: Application to the Removal of Aniline Based on the Electrochemical Polymerization on a Carbon Fiber. Environmental Science \& Technology. 2005;39(10):3805-10.

31. Cao H, Huang Y, Zhang Z, Sun J. Uniform modification of carbon fibers surface in 3-D fabrics using intermittent electrochemical treatment. Composites Science and Technology. 2005;65(11-12):1655-62.

32. Han S, Briseno AL, Shi X, Mah DA, Zhou F. Polyelectrolyte-Coated Nanosphere Lithographic Patterning of Surfaces: Fabrication and Characterization of Electropolymerized Thin Polyaniline Honeycomb Films. The Journal of Physical Chemistry B. 2002;106(25):6465-72.

33. Kumru ME, Springer J, Saraç AS, Bismarck A. Electrografting of thiophene, carbazole, pyrrole and their copolymers onto carbon fibers: electrokinetic measurements, surface composition and morphology. Synthetic Metals. 2001;123(3):391-401.

34. Luo Y, Zhao Y, Duan Y, Du S. Surface and wettability property analysis of CCF300 carbon fibers with different sizing or without sizing. Materials \& Design. 2011;32(2):941-6.

35. Kim TH, Vijayalakshmi S, Son SJ, Ryu SK, Kim JD. A Combined Study of Preparation and Characterization of Carbon Molecular Sieves (CMS) for Carbon Dioxide Adsorption from Coals of Different Origin. J Ind Eng Chem. 2003;9(5):481-7.

36. Park S-J, Kim B-J. Roles of acidic functional groups of carbon fiber surfaces in enhancing interfacial adhesion behavior. Materials Science and Engineering: A. 2005;408(1-2):26973.

37. Dilsiz N, Wightman JP. Surface analysis of unsized and sized carbon fibers. Carbon. 1999;37(7):1105-14.

38. Li J, Fan Q, Chen Z-h, Huang K-b, Cheng Y-I. Effect of electropolymer sizing of carbon fiber on mechanical properties of phenolic resin composites. Transactions of Nonferrous Metals Society of China. 2006;16, Supplement 2:s457-s61.

39. Satici MT, Sarac AS. Synthesis and Characterization of Poly(Acrylonitrile-coVinylacetate)/Fe2O3@PEDOT Core-Shell Nanocapsules and Nanofibers. International Journal of Polymeric Materials and Polymeric Biomaterials. 2015;64(11):597-609.

40. Sarac AS, Ates M, Kilic B. Electrochemical impedance spectroscopic study of polyaniline on platinum, glassy carbon and carbon fiber microelectrodes. Int J Electrochem Sci. $2008 ; 3(7): 777-86$. 
41. Sipahi M, Parlak EA, Gul A, Ekinci E, Yardim MF, Sarac AS. Electrochemical impedance study of polyaniline electrocoated porous carbon foam. Progress in Organic Coatings. 2008;62(1):96-104.

42. Sönmez G, Saraç AS. Structural study of pyrrole-EDOT copolymers on carbon fiber microelectrodes. Synthetic metals. 2003;135:459-60.

43. Sezgin S, Ates M, Parlak EA, Sarac AS. Scan rate effect of 1-(4-methoxyphenyl)-1H-pyrrole electro-coated on carbon fiber: characterization via cyclic voltammetry, FTIR-ATR and electrochemical impedance spectroscopy. Int J Electrochem Sci. 2012;7:1093-106.

44. Sarac AS, Gencturk A, Gilsing H-D, Schulz B, Turhan CM. Effect of Electrolyte on the Electropolymerization of 2,2-Dibutyl-3,4-Propylenedioxythiophene on Carbon Fiber Microelectrodes. Journal of Nanoscience and Nanotechnology. 2009;9(5):2877-86.

45. Sarac AS, Sezgin S, Ates M, Turhan CM, Parlak EA, Irfanoglu B. Electrochemical impedance spectroscopy of poly( $\mathrm{N}$-methyl pyrrole) on carbon fiber microelectrodes and morphology. Progress in Organic Coatings. 2008;62(3):331-5.

46. Popkirov GS, Barsoukov E, Schindler RN. Investigation of conducting polymer electrodes by impedance spectroscopy during electropolymerization under galvanostatic conditions. Journal of Electroanalytical Chemistry. 1997;425(1-2):209-16.

47. Deslouis C, Musiani MM, Tribollet B, Vorotyntsev MA. Comparison of the AC Impedance of Conducting Polymer Films Studied as Electrode-Supported and Freestanding Membranes. Journal of The Electrochemical Society. 1995;142(6):1902-8.

48. Dolas H, Sarac AS. Electrosynthesis of Poly(3-dodecyl thiophene) in Acetonitrile with Boron Trifluoride Diethyl Etherate: The Effect of the Electrolyte on Electrochemical Impedance and Morphology. Journal of The Electrochemical Society. 2011;159(1):D1-D8.

49. Sarac AS, Geyik H, Parlak EA, Serantoni M. Electrochemical composite formation of thiophene and $\mathrm{N}$-methylpyrrole polymers on carbon fiber microelectrodes: Morphology, characterization by surface spectroscopy, and electrochemical impedance spectroscopy. Progress in Organic Coatings. 2007;59(1):28-36.

50. Sarac AS, Sezgin S, Ates M, Turhan CM. Electrochemical impedance spectroscopy and morphological analyses of pyrrole, phenylpyrrole and methoxyphenylpyrrole on carbon fiber microelectrodes. Surface and Coatings Technology. 2008;202(16):3997-4005.

51. Dolas H, Sarac AS. An impedance-morphology study on poly(3-methylthiophene) coated electrode obtained in boron trifluoride diethyl etherate-acetonitrile. Synthetic Metals. 2014;195:44-53.

52. Dolas H, Sezer E, Sarac AS. Synthesis, Characterization and Electrochemical Polymerization of a Comonomer Bearing Thiophene and Imidazole: The Comparison of Impedance Behavior on Different Surfaces. ECS Journal of Solid State Science and Technology. 2016;5(5):P211P7.

53. Vishnuvardhan TK, Kulkarni VR, Basavaraja C, Raghavendra SC. Synthesis, characterization and a.c. conductivity of polypyrrole/Y2O3 composites. Bulletin of Materials Science. $2006 ; 29(1): 77-83$.

54. Macdonald DD. Reflections on the history of electrochemical impedance spectroscopy. Electrochimica Acta. 2006;51(8-9):1376-88. 


\title{
Türkçe Öz ve Anahtar Kelimeler
}

\section{Pirolün Elektropolimerleşmesi Üzerine Boyutlandırıcı Bileşiğin Etkisi ve Polipirol ile Kaplanmış Karbon Lifinin İmpedansı}

\author{
Hacer DOLAS, Digdem GIRAY and A.Sezai SARAC
}

\begin{abstract}
Öz: Karbon Lifi (CF), düşük ağılık, yüksek dayanırlık ve sertlik gibi mekanik özelliklerinden ötürü pek çok endüstri alanında yüksek performansa sahip reçine kompozitlerinde kuvvetlendirici malzeme olarak kullanılmaktadır. Kompozit malzemelerin mekanik performansları, onu oluşturan lif ve matrisin özelliklerine dayanır. Lif yüzeyinin özelliklerine etkide bulunan yöntemlerden biri, lif yüzeyinin ince filmle kaplanmasıdır. Lif elektropolimer ile kaplandığı zaman, kompozitin mekanik dayanıkılığı artmıştır. Bu çalışmada, karbon lifleri polipirol (PPy) ile elektrokimyasal olarak kaplanmış olup ortamda epoksi esaslı boyutlandırıcı bileşik (SC) vardır. Süreç boyunca SC'nin miktarı ile akımın, elde edilen kaplama ağırlıklarının ve impedans verisinin, özellikle kapasitansın, nasıl değiştiği incelenmiştir. Bu sebeple, farklı miktarda SC (\%0, \%0,18, \%1,8 v/v) elektrolit çözeltisi olan ve $0,1 \mathrm{M}$ pirol (Py) içeren $0,1 \mathrm{M} \mathrm{NaClO}_{4}-\mathrm{ACN}^{\prime} y e$ ilave edilmiştir. Kaplama işlemi Sabit Potansiyel veya Döngülü Voltammetri teknikleri ile yürütülmüştür. Diğer inceleme teknikleri gravimetrik analiz, elektrokimyasal impedans spektroskopisi, Fourier Transform İnfrared Spektroskopisi (FT-IR) ve Işık Mikroskopisidir. Kaplamanın sonunda, kaplamanın ağırlığı ve özgül kapasitansı (Csp), \%0 SC için 0,8 mg/g ve $114 \mu \mathrm{F}, \% 0,18$ $\mathrm{SC}$ için $10 \mathrm{mg} / \mathrm{g}$ ve $57 \mu \mathrm{F}$ ve $\% 1,8 \mathrm{SC}$ için $1,73 \mathrm{mg} / \mathrm{g}$ ve $166 \mu \mathrm{F}$ olarak bulunmuştur. Sonuç olarak, PPy ile kaplanmış karbon lifinin kaplanma ağırlığı ve kapasitans verisi (özellikle Csp), elektrolite ilave edilmiş SC'nin miktarı ile ters orantılı olarak değişmiştir.
\end{abstract}

Anahtar kelimeler: Elektropolimerleşme, Boyutlandırma, İmpedans ve Kapasitans.

Sunulma: 09 Haziran 2016. Düzeltme: 15 Ağustos 2016. Kabul: 17 Ağustos 2016. 